DOI: https://doi.org/10.35619/prap_rv.vi12.68

\title{
ПЕДАГОГІЧНІ ВПЛИВИ У СПОРТИВНИХ НЕФОРМАЛЬНИХ УГРУПУВАННЯХ ЯК МЕТОД СОЦАЛІЗАЦІї МОЛОДІ
}

Стаття присвячена аналізу педагогічних впливів у спортивних неформальних угрупуваннях як метод соціалізації молоді. Зростання значення неформальних угрупувань засвідчило їх помітну роль як умови соиіалізаиії особистості, в результаті чого вони стали об'єктом спеціального вивчення. Неформальне угрупування ми розглядаємо як організацію, що характеризується високим ступенем згуртованості, особистісним характером спілкування, нечітко вираженою метою групової діяльності і неформальним контролем, який грунтується на традиціях $i$ залежить від ступеня усвідомлення групового членства. Тим не менще неформальні молодіжні об'єднання футбольних фанатів в Україні поступово починають займати чільне місие серед інших неформальних угрупуваннях.

Ключові слова: неформальні угрупування, футбольні фанати, молодь, характер спілкування, соиіалізачія, неформальний контроль.

Статья посвящена анализу педагогических воздействий в спортивных неформальных группировках как способ соџиализаџии молодежи. Рост значения неформальных группировок показало их заметную роль как условия социализации личности, в результате чего они стали объектом специального изучения. Неформальное группирование мы рассматриваем как организацию, которая характеризуется высокой степенью сплоченности, личностным характером общения, нечетко выраженной целью групповой деятельности и неформальным контролем, который основан на традициях и зависит от степени осознания группового иленства. Тем не менее, неформальные молодежные объединения футбольных фанатов в Украине постепенно начинают занимать видное место среди других неформальных группировках.

Ключевые слова: неформальные группировки, футбольные фанаты, молодежь, характер общения, сочиализачия, неформальный контроль.

Постановка проблеми. Питання педагогічних впливів у спортивних неформальних угрупуваннях як метод соціалізації молоді є сучасним та актуальним в колі педагогів та психологів в традиційних структурах України.

На сучасному етапі розвитку нашого суспільства існує велика кількість неформальних молодіжних об'єднань та груп різного спрямування, які діють як на території нашої держави, так і в інших країнах світу. Серед них дедалі більшої популярності набувають неформальні угрупування спортивних (зокрема футбольних) фанатів.

Соціально-педагогічні дослідження, пов'язані 3 впливом різноманітних неформальних об'єднань молоді є досить актуальними на даний момент. Адже вплив неформального оточення на соціалізацію підростаючого покоління дослідниками у галузі соціальної педагогіки вже давно 3'ясований. Проте мало хто з науковців звертав увагу й, тим більше, досліджував неформальне об'єднання футбольних фанатів в цілому й особливості його впливу на сучасне молоде покоління. Тим не менше неформальні молодіжні об'єднання футбольних фанатів в Україні поступово починають займати чільне місце серед інших неформальних об'єднань. За останні роки їх кількість, як в Україні так і за їі межами стрімко зростає, а вплив даної субкультури на ії представників та молодь, яка не входить до цього об'єднання поступово збільшується. У межах кожної неформальної групи формується внутрішня субкультура. Мають значення одяг, зачіска, членам груп властива особлива поведінка, вони навіть виробляють власну, притаманну лише їм лексику.

Під молодіжною субкультурою розуміють культуру певного молодого покоління, яке володіє загальними стилем життя, поведінки, групових норм, цінностей та переконань. В складний період переходу із дитинства в доросле життя виникає дуже багато проблем, які не здатні вирішити молоді люди. Їм необхідна група ровесників, яким властиві ті ж проблеми, які мають ті ж цінності та ідеали. Для полегшення переходу із однієї крайності в іншу і необхідна молодіжна субкультура, яка акумулює в собі досвід вирішення всіх життєвих проблем, накопичений багатьма поколіннями молоді. 
Варто звернути увагу на парадокс молодіжних субкультур: з одного боку, вони культивують протест проти суспільства дорослих, його цінностей і авторитетів, а 3 іншого - покликані сприяти адаптації молоді до цього дорослого суспільства.

Аналіз останніх досліджень і публікацій. Існує цілий ряд соціально-психологічних факторів, які притягують неповнолітніх у асоціальні групи. Серед найбільш поширених такі: свобода і необмеженість діяльності - $97 \%$, наявність вільного часу - $96 \%$, відсутність нагляду й контролю з боку дорослих - 73 \%, прагнення до довірливого інтимно-особистісного спілкування $65 \%$. [6].

Зростання значення неформальних угрупувань засвідчило їх помітну роль як умови соціалізації особистості, в результаті чого вони стали об'єктом спеціального вивчення. Зокрема, досліджувались особливості соціально-педагогічної діяльності з дітьми та молоддю (В. Бочарова, Р. Вайнола, А. Капська, Л. Міщик); проблема створення та розвитку тимчасового колективу (Р. Бернс, В. Глазиріна); виховна робота в об'єднаннях за місцем проживання (А. Бойко, А. Рега, Я. Рейковський); діяльність неформальних молодіжних об'єднань (М. Малютін, Д. Ольшанський, В. Лісовський, А. Яковлєв).

Формулювання цілей статті: надати психолого-педагогічну характеристику спортивним неформальним угрупуванням, на прикладі футбольних фанатів.

Виклад основного матеріалу дослідження. Неформальні групи можуть бути організовані як у рамках формальних, так і поза ними. Перші є у рамках певних організацій, другі - існують незалежно від формальних. Вони утворюються на основі просторової близькості, спільності інтересів, психофізіологічних характеристик, особистої симпатії. Контакти в таких групах є глибші й ширші, більш значущі для індивідів. Саме такі групи мають значний вплив на соціалізацію особистості.

Життя і діяльність просоціальних груп регулюється не тільки нормами суспільної моралі, але й нормами права у процесі виховного профілактичного та корекційно-реабілітаційного впливу на них із боку адміністрації навчального закладу, педагогічного колективу, а також самодіяльних організацій молоді.

Кожному з нас доводилося йти по вулиці, їхати в транспорті або просто дивитись телевізор і бачити людей, які у чомусь не схожі на інших. У когось на голові ірокез, хтось увесь в металі, а хтось у чорній шкірі проноситься повз вас на мотоциклі. Найчастіше це і $є$ представники сучасних субкультур.

Представники різноманітних субкультур намагаються показати свою індивідуальність, сказати сірій масі: “Я - особистість", кинути виклик світу з його нескінченними буднями та вистроюванням усіх в один рядок. Молодь кожного дня у всіх країнах світу приймають ту чи іншу субкультуру. Тому необхідно знати про цю культурне явище, розуміти його та бути готовим зустрітися з представниками у реальному житті. Єдине, що учасниками у субкультурах приваблює в основному можливість спілкуватися 3 собі подібними, а також зовнішня атрибутика, яка дає можливість демонструвати свою позицію у соціумі.

Дослідженням проблеми фанатів, та фанатського руху займалось багато вчених, однак в більшості випадків досліджувалися певні групи фанатів, зокрема - футбольні хулігани, та й проводились ці дослідження здебільшого в Європі, адже ще в 1980 роки хуліганізм називали англійською хворобою. Дані дослідження носять більш соціологічний характер, ніж психологічний, у рамках психології дослідження проводились лиш у напрямку вивчення особистості фанатів. Непередбачуваний рух фанатів перетворився на стабільний елемент футбольного життя. Дане явище зародилося ще наприкінці $60-\mathrm{x}$ років, а його осередком стала Англія. Джон Гаррінгтон (британський психіатр) зробив першу серйозну спробу дослідження нового на той період явища футбольний хуліганізм. Його висновки було засновано на даних анкетного опитування та спостереження на футбольних матчах. Основна ідея Гаррінгтона полягала в тому,що причина футбольного насильства перш за все пов'язана 3 індивідуальною патологією та 3 реакціями на безпосередні подразники, що детерміновані умовами, в яких знаходились уболівальники [10, с.3031].

Альтернативні теоретичні підходи засновувались на критиці Гаррінгтона. Один 3 таких підходів представляв соціолог Ян Тейлор, який здійснив перше соціологічне дослідження футбольного хуліганства. Він стверджував, що комерціалізація футболу зумовила те, що гравці все більше віддалялися від глядачів, що їх підтримували, а насильство на футбольних матчах було своєрідною відповіддю останніх. Отже, насильство та агресія визначалися як спроба відновити контроль над грою. Аналіз Тейлора був і все ще залишається досить актуальним, про що свідчать численні дискусії навколо нього [10, с.33-34].

Випуск 12, 2019. Збірник наукових праць РДГУ 
Розуміння футбольного насильства як субкультурних стилів пропонувалися переважно соціологами 3 Центру сучасних культурних досліджень у Бірмінгемському університеті. Джон Кларк і Стюарт Галл виходили, зокрема, з того, що особливий субкультурний стиль дозволив молодим людям у специфічній формі вирішувати конфлікти, структурні і матеріальні проблеми. Щороку популярність спорту у світі стрімко зростає, створюється безліч програм для залучення молоді до різних видів спорту. Футбол не став виключенням: у нашій країні його популярність різко зросла після Євро - 2012p. Футбол здобув масу прихильників та фанатів. Часто оточуючі сприймають футбол як гру, що породжує агресію, а фанатів вважають вбивцями. Однак фанати середа далеко неоднорідна, а поведінка вболівальників досить різноманітна. Фанатизм - непохитна і не маюча жодної альтернативи прихильність індивіда певним переконанням, що виражається у його діяльності і спілкуванні. Фанатизм пов'язаний з відданістю ідеї та поєднується з нетерпимістю до інакомислячих, зневагою до етичних норм, що перешкоджає досягненню спільної мети. Найчастіше такі терміни, як фанат та фанатизм пов'язані з футболом і представляють собою організоване з середини співтовариство активних вболівальників, що живуть відповідно своїх правил та традицій.

Наступним компонентом колективних практик субкультури фанатів $є$ використання певного сленгу. Сленг футбольних фанатів, з одного боку, перебуває в процесі постійного змінення, а 3 іншого, він сформований настільки, що стороння людина не в змозі адекватно брати участь у розмові фанатів. Це пов'язано з тим, що словниковий запас фанатського сленгу досить великий, багато слів та словосполучень несуть додаткове змістовне навантаження [2]. Основна мета фанатського сленгу - відокремити фанрух від іншого світу, встановити критерій розподілу на «своїх» та «чужих». 3 іншого боку, існування достатньо розвиненого фанатського сленгу стратегічно невигідне, це суттєво ускладнює рекрутування нових членів. Переважна більшість фанатів - молодь, ті, хто «фанатіє» один-два роки та не має великої кількості «виїздів», але хоче мати певну перевагу над новими членами руху, яку демонструють завдяки використанню сленгу. В той же час вони не мають можливості активно розвивати сленг, тому що їм бракує авторитету в середовищі фанатів. Зазвичай фанатський сленг супроводжує колективні практики та те, що з ними пов'язане. Колективні практики футбольних фанатів дуже різноманітні, вони $є$ ключовим компонентом усієї фанатської субкультури. Допоміжними засобами здійснення певних практик $\epsilon$ сленг та атрибутика [2].

Для субкультури молодіжних груп спорт в теперішній час став зручною ареною виплеску прагнення до самовираження на тлі недостатнього культурного потенціалу натовпу фанатів, які зосереджуються біля спорту - це саме молодіжний феномен. Причому цей натовп в дійсності байдужий до спорту, він знаходиться не в спорті, але в суспільстві, й тому є соціальною проблемою. Фанатичні рухи в своїй основі постають як самоорганізація молоді в умовах недостатньо збалансованої державної молодіжної політики. «Фанатичний» натовп, як й інші види масових видовищних натовпів - це не просто певні соціальні феномени, на які повинні професійно реагувати в основному правоохоронні органи. Це, перш за все, соціальна проблема.

У молодіжній навколо спортивній субкультурі, що характеризується низьким рівнем рефлексії, посилюються орієнтації на груповий егоїзм, що проявляється у захисті індивідуальних інтересів через інтереси групові за допомогою використання будь-яких засобів - від неформальних до кримінальних; активізується процес стихійного порівняння свого соціального статусу с позиціями інших людей як незаслуженого і несправедливого, що викликає особливо агресивний тип поведінки.

Футбольні фани в сучасному своєму вигляді - досить молодий громадський рух. Футбольних уболівальників можна віднести як до гедоністично-розважальних, так і до анархонігілістичних субкультур. Пояснити це можна тим, що, з одного боку, футбол - гра, шанувальники якої приходять, щоб приємно і цікаво провести час, висловити свою підтримку команді, розрядитися або ж навпаки отримати новий заряд енергії. Вони не мають на меті насильницьких дій чи агресію, тому можна цю субкультуру назвати гедоністично-розважальною. 3 другого боку, спортивні фани найбільш віддані вболівальники, готові до будь-якого виду насильства щодо прихильників інших команд, обстоюючи свою думку [1].

Висновки $з$ даного дослідження і перспективи подальших розвідок у даному напрямку. Таким чином, проведене дослідження дозволяс говорити про чітке уявлення футбольних фанатів про себе, про їх достатньо жорстку ідентифікацію з собі подібними - 3 одного боку, і про їх нерішучість та неспроможність приймати відповідні рішення за межами фан-руху - з іншого. Крім того їх інтереси $є$ досить вузькими і охоплюють лише сферу вболівання. Тому з нашої точки зору, 
певну цікавість можуть представляти дослідження життєвої перспективи мотиваційно-ціннісної сфери футбольних фанатів.

Проблема роботи 3 спортивними фанатами, не в останню чергу, пов'язана 3 відсутністю лідера, бурею емоцій і культурним та мовним бар'єром. Проблеми комунікації з представниками інших культур можуть перешкодити правоохоронцям адекватно виконувати превентивні заходи по відношенню до агресивно налаштованим уболівальникам.

Отже, у неформальних угрупованнях формується протиправна кримінальна поведінка. Цьому сприяють вседозволеність у цих групах, бажання бути дорослішими і незалежними від батьків. Часто «ефект групи» поглинає людину, вона втрачає свою особистість, робить протиправні вчинки, будучи «зараженою» тим, що це роблять інші. Допомогти їм можна лише створивши інше середовище спілкування, де б молоді люди не перетиналися би зі своїми колишніми друзями [3, c.78]. Також визначили що субкультура футбольних фанатів негативно впливає на суспільство, соціальний порядок. У своїй роботі соціальний працівник може використовувати як індивідуальні, так і групові методи соціальної роботи. Спеціалісти пропонують ряд тренінгів і програм на усунення агресії і поліпшення навичок спілкування у суспільстві, тренінги вирішення конфліктів, тренінги міжкультурного взаєморозуміння і рольові ігри [5].

Таким чином проведений теоретичний аналіз літератури дозволяє зробити висновки про більш публіцистичний та соціологічний характер досліджень та брак, суто психолого-педагогічних досліджень футбольного фанатизму. Тому перспективною метою нашої роботи має бути дослідження особливостей групової ідентифікації футбольних фанатів та любителів футболу.

Отже, можна зробити висновок, що в Україні рух футбольних фанів $є$ окремою сформованою субкультурою, яка має свої особливості (ієрархію, сленг, принципи залучення до руху тощо) і характеризується негативним ставленням до комерціалізації сучасного українського футболу.

\section{Список використаних джерел}

1. Бочелюк В. И. Психологія спорту / В. И. Бочелюк, О. А. Черепєхіна. - Київ : Центр учб. літ., 2007. - 224 с.

2. Запобігання злочинам, що вчиняються радикальними молодіжними угрупованнями під час футбольних матчів : метод. рек. / С. С. Чернявський, I. М. Копотун, О. А. Лупало та ін. ; за заг. ред О. М. Джужі. - Київ : Київ. нац. ун-т внутр. справ, 2010. - 56 с.

3. Косарецкая С. В. О неформальных объединениях молодежи / С. В. Косарецкая, Н. Ю. Синягина. - М. : Гуманит. изд. центр ВЛАДОС, 2004. - 159 с.

4. Леко Б. Розвиток вольових якостей у студентів-спортсменів / Б. Леко, Г. Чуйко, М. Комісарик // Теорія та практика фізичного виховання. - 2008. - № 5. - С. 6-10.

5. Ложкін Г. Професійний розвиток особистості майбутнього 199 спортивного психолога / Г. Ложкін // Вища освіта України. - 2006. - № 4. - С. 75-79.

6. Молодежная субкультура. Введение [Электронный ресурс]. - Режим доступа: http://www.vk.kiev.ua.

7. Осипова А. А. Справочник психолога по работе в кризисных ситуациях / А. А. Осипова. - Ростов-н/Д. : Феникс, 2005. - 315 с.

8. Розов В. І. Психологічне забезпечення діяльності в екстремальних ситуаціях / В. І. Розов // Соціальна психологія. - 2007. - № 4 (24). - С. 174-188.

9. Чернета С. Ю. Самодіяльні молодіжні об’єднання як фактор формування соціальної активності особистості / С. Ю. Чернета // Теоретико-методичні проблеми виховання дітей та учнівської молоді : зб. наук. пр. - Київ, 2002. - Кн. 2. - С. 118-122.

10. Brimson D. Kicking Off: Why Hooliganism and Racism Are Killing Football / D. Brimson. London, 2006. -210 p.

\section{References}

1. Bocheliuk V. Y. Psykholohiia sportu / V. Y. Bocheliuk, O. A. Cherepiekhina. - Kyiv : Tsentr uchb. lit., 2007. - $224 \mathrm{~s}$.

2. Zapobihannia zlochynam, shcho vchyniaiutsia radykalnymy molodizhnymy uhrupovanniamy pid chas futbolnykh matchiv : metod. rek. / S. S. Cherniavskyi, I. M. Kopotun, O. A. Lupalo ta in. ; za zah. red O. M. Dzhuzhi. - Kyiv : Kyiv. nats. un-t vnutr. sprav, 2010. - 56 s.

3. Kosaretskaia S. V. O neformalnыkh obъedynenyiakh molodezhy / S. V. Kosaretskaia, N. Yu. Syniahyna. - M. : Humanyt. yzd. tsentr VLADOS, 2004. - 159 s. 
4. Leko B. Rozvytok volovykh yakostei u studentiv-sportsmeniv / B. Leko, H. Chuiko, M. Komisaryk // Teoriia ta praktyka fizychnoho vykhovannia. - 2008. - № 5. - S. 6-10

5. Lozhkin H. Profesiinyi rozvytok osobystosti maibutnoho 199 sportyvnoho psykholoha / H. Lozhkin // Vyshcha osvita Ukrainy. - 2006. - № 4. - S. 75-79.

6. Molodezhnaia subkultura. Vvedenye [Elektronnyi resurs]. - Rezhym dostupu : http://www.vk.kiev.ua

7. Osypova A. A. Spravochnyk psykholoha po rabote v kryzysnыkh sytuatsyiakh / A. A. Osypova. - Rostov-na-Donu : Fenyks, 2005. - 315 s.

8. Rozov V. I. Psykholohichne zabezpechennia diialnosti v ekstremalnykh sytuatsiiakh / V. I. Rozov // Sotsialna psykholohiia. - 2007. - № 4 (24). - S. 174-188.

9. Cherneta S. Yu. Samodiialni molodizhni obiednannia yak faktor formuvannia sotsialnoi aktyvnosti osobystosti / S. Yu. Cherneta // Teoretyko-metodychni problemy vykhovannia ditei ta uchnivskoi molodi : zb. nauk. pr. - Kyiv, 2002. - Kn. 2. - S. 118-122.

10. Brimson D. Kicking Off: Why Hooliganism and Racism Are Killing Football / D. Brimson. London, 2006. - $210 \mathrm{~s}$.

\section{R. Musket., P.V. Krindrat, O. O. Demchuk PEDAGOGICAL INFLUENCES IN SPORTS INFORMAL GROUPS AS A METHOD OF SOCIALIZATION OF YOUTH}

The article is devoted to the analysis of pedagogical influences in sports informal groups as a method of socialization of youth. The growth of the importance of informal groups has shown their prominent role as the conditions for socialization of the individual, as a result of which they became the object of special study. We consider the informal group as an organization characterized by a high degree of cohesion, a personal character of communication, an unclear purpose of group activity and informal control, which is based on traditions and depends on the degree of awareness of group membership. Nevertheless, informal youth associations of football fans in Ukraine are gradually beginning to occupy a prominent position among other informal groups.

Informal groups form an unlawful criminal behavior. This is facilitated by permissiveness in these groups, the desire to be older and independent of their parents. Often, the "effect of a group" absorbs a person; it loses its personality, makes illegal acts, being "infected" by the fact that others do it. It is possible to help them only by creating a different communication environment where the teenager would not cross with his former friends.

At the present stage of development of our society, there are a large number of informal youth associations and groups of diverse backgrounds that operate both in our country and in other countries of the world. Among them, more and more popular are informal groups of sports (including football) fans.

Key words: informal groupings, football fans, youth, character of communication, socialization, informal control.

\section{УДК: 159.96+316.64+004.2}

DOI: https://doi.org/10.35619/prap_rv.vi12.69

\section{В. В. НАЗАРЕВИЧ, О. В. П'ЯСЕЦЬКА}

\section{ОСТРАКІЗОВАНІ ОЗНАКИ АУТОАГРЕСИВНОЇ ПОВЕДІНКИ ПІДЛІТКІВ}

У статті розкрито особливості багатоаспектного явища підліткової аутоагресії та зв'язок аутоагресивних проявів. Основну увагу направлено на дослідження причин саморуйнівних дій, що реалізуються внаслідок послаблення інстинкту самозбереження в поєднанні з депресивним афектом. Здійснено аналіз вікових характеристик аутоагресорів, які впливають на початок аутоагресивної поведінки внаслідок незадоволених соиіальних потреб.

Ключові слова: остракізачія, аутоагресія, аутодеструкиія, самопошкодження без суїиидальних намірів, підліткова депресія.

В статье раскрыты особенности многоаспектного явления подростковой аутоагрессии, проведена связь аутоагрессивного поведения с депрессией различной тяжести. Основное внимание направлено на исследование причин саморазрушающих действий, реализуемых в результате ослабления инстинкта самосохранения в сочетании с депрессивным аффектом. Осуществлен анализ возрастных характеристик аутоагрессоров, что влияют на начало аутоагрессивного поведения вследствие неудовлетворенных соииальных потребностей.

Ключевые слова: остракизаиия, аутоагрессия, аутодеструкиия, самоповреждение без суицидальных намерений, подростковая депрессия. 